\title{
Ten Tips for a Crisis: Lessons From a Soldier
}

\author{
Mark Hertling, DBA
}

Lieutenant General, US Army (Retired); Military and International Affairs Analyst, CNN, Atlanta, Georgia; Former Senior Vice President for Global Partnering, Health Performance Strategy, and Physician Leadership, Florida Hospital, Orlando, Florida; Adjunct Scholar, Modern War Institute at West Point, US Military Academy, West Point, New York; Adjunct Professor, Crummer School of Business, Rollins College, Orlando, Florida.

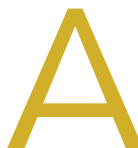

few days ago, I had a heartfelt conversation with my good friend Dr Omayra Mansfield. Dr Mansfield has been an Emergency Department Physician for more than 12 years. She is also the wife of another physician and the mother of two young children, the recently appointed Chief Medical Officer at a hospitals at AdventHealth, and one of the first graduates of the Physician Leader Development Course I teach.

"During the leadership course, you always provided examples of how physicians are like soldiers," she began. She reminded me of my words describing how both doctors and soldiers are part of a professional body, how both have a cherished ethos and a set of directing values to guide both their path and their actions as a very special part of our society, and how of all the professions in our society, the military and medicine are the only two that deal in life and death, albeit in very different ways.

She had certainly paid attention in our seminars. Now, as she and her team faced the COVID-19 pandemic, she realized their daily challenges are expanding and they are now going to war. The leadership discussions that had sparked so much debate in our colloquia had now become real.

Dr Mansfield explained that beyond caring for patients, one of her key concerns was the physical and emotional well-being of the clinical staff at her hospital: the physicians, nurses, technicians, and clinicians under her care. Getting to her point, she asked if I might have any suggestions based on my time and experiences in combat that might be helpful to her as she "cared for her troops" as they faced the battle ahead.

Her request was a good one. Lessons from my military past immediately rushed to my mind. I started scribbling and came up with a Top Ten list of recommendations for anyone going into a tough fight. Here's what I sent to her:

1. Find a battle-buddy. On the first day of Army basic training, drill sergeants pair new recruits with one another. That's primarily for accountability purposes throughout the weeks of trainingto ensure soldiers hold each other responsible for getting to the right place, at the right time, in the right uniform—but it's also part of a larger psychological dynamic related to building teams

Corresponding Author: Mark Hertling, DBA; Email: mphertling75@gmail.com; Twitter: @markhertling.

Published online first April 2, 2020

Received: March 31, 2020; Accepted: March 31, 2020

๑ 2020 Society of Hospital Medicine DOI 10.12788/jhm.3424 and mutual support within organizations. Your battle-buddy is charged with keeping you out of trouble, having your back, and being there when you need it most. In combat, battle-buddies do all those things and then some; they protect you from harm in so many other ways. Healthcare providers during this crisis will sometimes feel all alone, and they need to rely on someone else to help them when times get really tough. Having a battle-buddy_for those at the healthcare team level, of course, but also among those at the level of clinical director, hospital administrator, $\mathrm{CMO}$, or even CEO_-will help get you through the tough times and provide sanity when you need it the most. So my first piece of advice: Find a battle-buddy.

2. Plan and prepare for things you don't expect will happen. During a preparatory training exercise for our unit's deployment to Iraq during the surge, when we thought the exercise was about to end, the trainers surprised us with a final crisis we had to solve. According to the scenario, Al Qaida had blown up a major bridge in our area, causing dire logistical problems for the security forces and challenges to the population as they brought their goods to market. I remember my initial reaction: "They don't have the strength to do that. This'll never happen," I said to the Chief of Staff under my breath, as we started developing the required drill to counter the action and please the trainers. I quickly forgot about that lesson, until after we deployed. Two weeks into our 15-month tour in Iraq, the enemy blew the exact bridge that was part of the scenario, causing the exact problems that were predicted. Because we had prepared for the unexpected, we were able to quickly repair the bridge, reestablish the logistics flow, and satisfy the worried population. The lesson: Teams can hope for the best, but it's always important to prepare for the worst-a lack of equipment, a key member of the team not being available to contribute, an overwhelming surge of patients-and then develop a plan to mitigate it. Take time to reflect, and ask yourself, What is the worst that can happen, what can the "enemy" do to disrupt our lives, and how do we prepare to counter it?

3. Get everyone into the fight. In every organizations, it's often true that some people take on too much and try and do it all themselves, others do only what they're told to do, there's the unique few who want to contribute but don't know how they can to help, and then there's some who even attempt to avoid contributing at all. It's important for leaders to know who on their team fits each of these categories. It's even more critical for leaders to be able to find ways to relieve the overworked, assign tasks to those who might not know their role, bring those who want to contribute into the fold, and cross- 
train teams to help relieve those who are exhausted. Leaders must look across their "battlespace" and ensure everyone is contributing. Leaders assign everyone tasks and do their best to level-and lighten - the load of the overworked.

4. "Fatigue makes cowards of us all." During any type of crisis, the body and mind will rapidly break down from lack of sleep, emotional strain, or overwhelming stress. While a 12hour shift in a hospital is exceedingly tough even during normal operations, the COVID-19 crisis will demand dramatically more of all the members of any healthcare team. For that reason, leaders must incorporate rest cycles, team rotations, and half-days away from the hospitals even when all hands are on deck, as well as consider reducing shift times, if possible. Many who have experienced the disease in hot spots say this is really tough, but not attempting to plan for this will cause eventual breakdown and dysfunction. Take a break, do all you can to maintain a modicum of balance, and get away for a while.

5. Take time to huddle. Communication and information are always key, but especially critical during any crisis. One technique that has proven valuable, beyond meetings and shift changes, is a preshift and postshift huddle. Different from the formal passing of critical information, the huddle is a brief opportunity for teams to pass informal information, look each other in the eye, and perhaps even pray together. As a two-star general, I did that every morning in combat with my small team of sergeants, captains, and privates before we left the headquarters to visit units, and it gave us all the power of knowing we had shared information, and we had a common operating picture. It gave us strength. During a crisis, all kinds of communication, formal and informal, are key.

6. This ain't peacetime. In a crisis, the enemy gets a vote. If leaders don't find ways to counter the enemy's action (and fast!), they'll be behind the curve! It's important to find the techniques and procedures that are bureaucratic (or even dumb) and overturn or eliminate them quickly. Decisions must be made with alacrity and with an understood flow, and people must be assigned responsibilities and held accountable to make things happen. In a crisis, speed in action will almost always trump perfection in understanding. Stay calm but ensure that those who might not understand this come around to the dynamics associated with the threat. A crisis isn't the time for business as usual.

7. Force adaptation-don't wait 'til things are over to adjust. In a crisis, faults and disconnects in techniques and procedures often bubble to the surface and cause consternation. Don't wait for a break in the action to adjust and find new ways to do things because a break in the action will usually never happen. The military has an expression: "Those who adapt the fastest on the battlefield win." Find ways to look for and then publicize your methods of adaptation to the team, pin the rose on someone to ensure the changes are made, and then have someone make a historical record so other teams might also learn from your scar tissue. Lessons from the fight must be incor- porated by the organization, or they're not "lessons learned."

8. Talkin' ain't fightin'. During a crisis, it's important to establish techniques of verbal shorthand between the members of a team, and everyone must know their responsibilities and required actions. In the military, this is called a battle drill; in medicine, you know it as a code. In these situations, leaders must find ways to pass information quickly, and the reaction should be immediate response. In a crisis, normal process must take on the dynamics of a "code." All members of the team must understand that there are just times when things can't be explained, but it's also important that leaders know when to use this abbreviated format. Explain when you can, but act when you must.

9. Cherish your teams. Every single team will experience things that human beings aren't designed or meant to handle-even those in the medical profession, who likely thought they had seen it all. There will be repeated and overwhelming trauma, with the expected emotional reactions. The approach during these situations requires empathy, humility, emotional understanding, and validation. Praise your team at every opportunity, find ways to turn mistakes into learning opportunities, but most importantly be human and find ways to provide memories that your team can cherish and look back upon. Give them memories.

10. Leaders don't have the right to have a bad day. In 2004, after a 12-month deployment in Iraq, our unit was on our way home. We had been a long time away from our families, and we had experienced some tough fighting. A third of our unit had already returned to their families in Germany when we were told we would be extended because of a changing situation on the ground. A wave of frustration went through our 18,000 soldiers. Our commander then pulled us together, communicated our new mission, and told us he was also disappointed, but it was time we had to show our grit by getting those soldiers who had already returned to Europe back, unpack our equipment, and return to the fight. Then he said something I will always remember: "It's tough, but understand your soldiers are looking at you to lead in this crisis ... and leaders don't have the right to have a bad day." He didn't mean we couldn't be frustrated, or disappointed, or emotional, or even pissed off. He meant we just couldn't show it when others were around. That's one of the toughest things about leading during a crisis: The unimaginable is expected of leaders. And leaders have to be ready to lead.

All this advice may seem like philosophical musings rather than pragmatic thoughts for a crisis, but hopefully this advice will make a difference as healthcare providers tackle the issues ahead. Stay healthy, mitigate risks, but know that the calm provided by leaders will make a difference.

Disclosures: The author has nothing to disclose. 